\title{
Vitenskapelig originalitet på toppnivå
}

\author{
I jakten på noe nytt kan kreative forskere finne på å studere nesten hva som helst. En fare som \\ lurer i buskene er at dette ender med bare tull, selv om intensjonen var den aller beste.
}

| 1999 ble norske lesere gjort oppmerksomme på at det eksisterte en amerikansk parodi på de årlige nobelprisene, kalt lg Nobel Prize. Den blir utdelt under en høytidelig seremoni ved det prestisjetunge Harvard University i begynnelsen av oktober hvert år. Komiteen gir hver gang ti priser for usedvanlige eller høyst trivielle funn. I begrunnelsen ligger det ofte en underforstått kritikk eller forsiktig satire, mens andre ganger kan formålet være å fremheve virkelig original forskning. Derfor er den dypere hensikten at offentliggjørelsen av prisene skal få folk til å le først og siden tenke.

Ig-nobelprisen er fyldig presentert på Wikipedia, og her finnes også en liste over prisvinnere og begrunnelse for tildelingene siden starten i 1991. Visste dere f.eks. at duer kan trenes opp til å skille mellom malerier av Picasso og Monet? Hva med en avhandling som viser at mennesker som har vansker med å innse sin egen inkompetanse også overvurderer sine egne evner? Eller funnet som en virkelig nobelprisvinner i fysikk har publisert, at man kan løfte en frosk ved hjelp av magneter? En artikkel fra et indisk institutt for mental helse som konkluderer med at å pille seg i nesen er alminnelig hos voksne, vekker også oppmerksomhet. Ganske nyttig var en matematisk avhandling om hvordan man kan anslå totaloverflaten hos indiske elefanter.

Imponerende var også avhandlingen til prisvinnerne i biologi i 2004. De kom fra Canada, Danmark og Sverige og presenterte en vitenskapelig artikkel om at sild kommuniserer ved hjelp av à fjerte. Verken mer eller mindre. Av medisinsk interesse er en prisbelønnet avhandling om at intraktabel hikke kan behandles ved å massere rectum med en finger. Eller at hamstere kommer seg raskere av jetlag etter oversjøiske flyreiser hvis de får
Viagra. Et annet viktig og prisbelønnet funn var at kostbare placeboer er mer effektive enn placeboer som er billige. Det mest imponerende på forfattersiden var et medisinsk arbeid som hadde fire hovedforfattere og 972 medforfattere, eller hundre ganger så mange som det var sider i artikkelen.

Grunnen til at dette viktige tiltaket ble presentert i Tidsskriftet i 1999 er at Arvid Vatle, som i mange år har arbeidet som allmennlege på Stord, selv fikk prisen det året og overvar den høytidelige seremonien. Originalartikkelen hans som var grunnlaget for prisen, skal vi komme tilbake til senere. Den komplette litteraturlisten til de norske prisvinnerne så langt presenteres nedenfor (1-5). Konklusjonen er at noe mer spennende enn vitenskap kan man ikke drive med.

\section{Ole Didrik Lærum}

ole.laerum@gades.uib.no

Ole Didrik Lærum (f. 1940) er professor (adj.) ved Københavns Universitet og professor emeritus ved Universitetet i Bergen

\section{Litteratur}

1. Bakkevig MK, Nielsen R. Impact of wet underwear on thermoregulatory responses and thermal comfort in the cold. Ergonomics 1994: 37: 1375-89.

2. Kleist E, Moi H. Transmission of gonorrhoea through an inflatable doll. Genitourin Med 1993; 69: 322.

3. Baerheim A, Sandvik H. Effect of ale, garlic, and soured cream on the appetite of leeches. BMJ 1994: 309: 1689.

4. Vatle A. Unyttig om urinprøver. Tidsskr Nor Lægeforen 1999; 119: 1178-9.

5. Teigen KH. Is a sigh «just a sigh»? Sighs as emotional signals and responses to a difficult task. Scand J Psychol 2008: 49: 49-57.

\section{Fenomenet Ig Nobel-prisen}

Arvid Vatle. Fenomenet Ig Nobel-prisen. Tidsskr Nor Lægeforen 1999; 119: 4617.

\begin{abstract}
Ved det ærverdige Harvard-universitetet blei dei ikkje fullt så ærverdige Ig Nobelprisane i september utdelt for niande gong etter starten i 1991. Kva er no dette for eit fenomen?
\end{abstract}

Forhistoria byrja i Israel. Der grunnla virologen Alexander Kohn og fysikaren Harry Lipkin i 1955 The Journal of Irreproducible Results. Artiklane i dette tidsskriftet kunne ofte vere karikaturar av vitskaplege avhand- lingar. Dei kunne også med humor avsløre det pompøse, oppblåste og uekte ved visse sider av vitskap, politikk og religion.

I 1990 vart tidsskriftet selt og Marc Abrahams fra Massachusetts Institute of Technology vart redaktør. Like før Alexander Kohn døde i 1994, hjelpte han Marc Abrahams med å stifte The Annals of Improbable Research, som er arvtakaren til The Journal of Irreproducible Results.

\section{Vekk med gravalvoret}

I 1991 arrangerte Marc Abrahams den første utdelinga av det han kalla Ig Nobelprisen, på ti ulike område. Dette har utvikla seg til å bli ein ekte morofest kvar haust på Harvard-universitetet. I 1998 vart det til dømes utdelt ni prisar på så ulike felt som konstruksjon av personleg verneutstyr, biologi, fred, kjemi, folkeopplysning om vitskaplege framsteg, statistikk, fysikk, økonomi, medisin og litteratur. 
I prinsippet er det her forskarar som driv gjøn med andre forskarar ved å utøve humoristisk kritikk. Det er såleis viktig å kome i hug at Annals of Improbable Research og Ig Nobel-prisutdelinga ikkje er vitskapsfiendtlege. Fenomenet representerer heller eit forsøk på å ta bort det gravalvorlege og pompøst sjølvhøgtidlege ved enkelte sider av vitskapen og representantar for denne. Samstundes vil dei stimulere interessa for vitskap.

Nokså typisk er det at Ig Nobel-prisen for litteratur i 1993 gjekk til fire namngitte forfattarar og 972 anonyme medforfattarar til ein artikkel i The New England Journal of Medicine. Artikkelen hadde hundre gonger så mange forfattarar som sider.

\section{Tre nordmenn}

Kven som helst kan nominere kven som helst, inkludert seg sjølve. Men det har berre skjedd ein einaste gong at sjølvnominerte har vunne ein pris. Inntil 1999 har tre av til saman 78 prisar i perioden 1991-98 hamna hos nordmenn. I 1995 gjekk prisen i offentleg helsearbeid til Martha Kold Bakkevig fra Trondheim og Ruth Nielson fra Danmark. Dei hadde skrive om korleis vått undertøy påverka termoregulatoriske reaksjonar (Ergonomics 1994; 37: 1375-89).

I 1996 vann Anders Bærheim og Hogne Sandvik biologiprisen for ei avhandling om korleis øl, kvitløk og rømme påverkar appetitten til blodigler (BMJ 1994; 309: 1689).

I 1996 også Harald Moi saman med Ellen Kleist frå Grønland prisen i offentleg helsearbeid. Dei hadde produsert ein nøktern artikkel som behandla faren for eventuell overføring av gonoré gjennom ei oppblåsingsdokke (Genitourinary Medicine 1993; 69: 322).

Kjenner du nokon som er verd ein pris? Aktuell og nødvendig informasjon kan sendast til Marc Abrahams, e-post: marca@chem2.harvard.edu

Les meir om Ig Nobel-prisen på Internett: www.improbable.com/ig/ig-top. html - Arvid Vatle

\section{Årets medisinpris til nordmann}

Allmennlege Arvid Vatle fra Stord mottok 30. september Ig Nobel-prisen 1999 imedisin. Han fikk den for «carefully collecting, classifying, and contemplating which kinds of containers his patients chose when submitting urine samples.» Artikkelen Unyttig om urinprøver ble publisert i årets påskenummer av Tidsskriftet (Tidsskr Nor Lægeforen 1999; 119: 1178-9). Vatles artikkel fikk, ikke uventet, store oppslag i Norges største og minste aviser og han ble intervjuet $i$ et mangfold av radiokanaler rundt påsketider.

Gjennom et helt år hadde Vatle samlet emballasje som pasientene brakte urinprøver i til legekontoret. Han hadde registrert 110 ulike flasker og glass. Den desiderte gjengangeren blant det totale utvalget på 164 var Stavlands tomatpuré med Delikat Appetittsild $270 \mathrm{~g}$ som en god nummer to. Hyppigheten av tomatpuréglass hadde fått Vatle til å lure på om tomatpuré kunne forårsake urinveisinfeksjon.

Under utdelingen ved Harvard-universitetet uttrykte Arvid Vatle forbauselse over hvor godt rengjort emballasjen var: - Jeg var positivt overrasket over at jeg aldri fikk en positiv glukosereaksjon i et glass som opprinnelig hadde inneholdt sukkerholdig drikke eller søt mat, sa han.

Årets utdeling samlet 1200 mer eller mindre eksentriske tilskuere $\mathrm{i}$ auditoriet ved Harvard-universitetet. Det er ekte nobelprisvinnere som overrekker Ig Nobel-prisene og det er åtte ekte vinnere som sitter i juryen. I tillegg blir to tilfeldige personer hentet inn til juryen fra gaten. Begivenheten blir kringkastet både i TV og radio og vinnerne må holde en takketale på under ett minutt. To dager etter utdelingen holdt Arvid Vatle en obligatorisk forelesning om sitt emne ved Harvard Medical School.

Ikke helt pålitelige kilder hevder at betegnelsen Ig står for Ignatius Nobel, en hittil ukjent bror av Alfred Nobel. Mer trolig er det at det står for Ig-nominius, altså uttrykk for noe som er lite ærerikt.

- Som den enkle sjelen jeg er, føltes det som en stor ære å få prisen. Derfor liker jeg best ideen om Alfred Nobels ukjente bror, sier Arvid Vatle til Tidsskriftet. - Nina Husom, Tidsskriftet nina.husom@legeforeningen.no

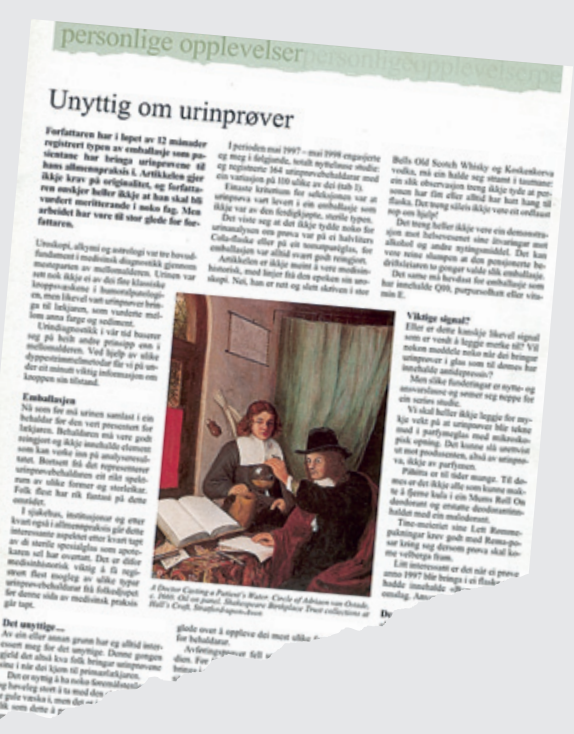

